\title{
SUPERVISOR PENDIDIKAN ISLAM DALAM PERSPEKTF AL-QUR'AN
}

\author{
Sahlani \\ Sahlaros44@yahoo,com \\ (Fakultas Agama Islam, Universitas Muhammadiyah Tangerang)
}

\begin{abstract}
Abstrak:
Pendidik berkaitan langsung terhadap kualitas pendidik dan peserta didik dalam menjalankan kewenangan seorang supervaisor dalam tata kelola pendidikan yang menyentuh langsung terhadap peserta didik, Dalam upaya meningkatkan hasil dan mutu pendidikan, kompetesi pimpinan dan kompetensi pengawasan terhadap hasil yang diharapkan, merupakan salah satu faktor yang sangat penting. Kompetensi kepemimpinan harus memiliki kompetensi kepribadian, kompetensi manajerial, kompetensi kewirausahaan, kompetensi supervisi dan kompetensi sosial yang kesemuanya tidak terlepas dari wawasan dan nilai-nilai al-Qur'an. Sedangkan kompetensi pengawas sekolah meliputi kompetensi kepribadian, kompetensi supervisi manajerial, kompetensi supervisi akademik, kompetensi evaluasi pendidikan, kompetensi penelitian dan pengembangan dan kompetensi sosial.
\end{abstract}

\section{Kata kunci: Kewenangan, Supervaisor, Pendidikan Islam, Perspektif al-Qur`an.}

\section{Abstract:}

Educators are directly related to the quality of educators and students in exercising the authority of a supervaisor in education governance that touches directly on students, In an effort to improve educational outcomes and quality, leadership competence and supervisory competence on expected results is one very important factor. . Leadership competence must have personality competence, managerial competence, entrepreneurial competence, supervisory competence and social competence, all of which cannot be separated from the insights and values of the Qur'an. Meanwhile, the competence of school supervisors includes personality competence, managerial supervision competence, academic supervision competence, educational evaluation competence, research and development competence and social competence.

Keywords: Authority, Supervaisor, Islamic Education, Al-Qur'an Perspective.

\section{A. Pendahuluan Pendahuluan}

Berdasarkan firman Allah dalam QS: At-Taubah/9: 105

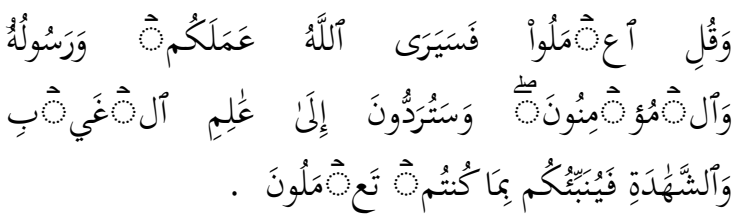

Dan Katakanlah: "Bekerjalah kamu, Maka Allah dan Rasul-Nya serta orang-orang mukmin akan melihat pekerjaanmu itu, dan kamu akan dikembalikan kepada (Allah) yang mengetahui akan yang ghaib dan yang nyata, lalu diberitakan-Nya kepada kamu apa yang telah kamu kerjakan. ${ }^{1}$

Berdasarkan ayat tersebut di atas, Allah SWT, memerimtahkan kepada setiap orang yang beriman kepada-Nya, agar selalu melakukan perbuatan dan tindakan

\footnotetext{
${ }^{1}$ Departemen Agama Republik Indonesia, Al-Quran dan Terjemahnya
} 
yang menjadi kerja nyata dalam membantu dan meningkatkan kualitas dan kemajuan terhadap nilai-nilai kemulyaan setiap manusia melalui proses pembelajaran dan pengawasan. Karena setiap amal perbuatan itu Allah, Rasul-Nya, serta orang-orang yang beriman akan melihat, dan Allah akan tunjukkan sebagai bukti kerja nyata yang dilakukan setiap manusia. Dinamika pendidikan nasional sedang mengalami perubahan yang cukup mendasar, terutama berkaitan dengan manajemen dan kurikulum yang diikuti oleh perubahanperubahan teknis lainya. Dalam upaya meningkatkan mutu pendidikan nasional, pemerintah khususnya melalui Depdikbud terus menerus berupaya melakukan berbagai perubahan dan pembaharuan sistem pendidikan kita. Salah satu upaya yang sudah dan sedang dilakukan, yaitu berkaitan dengan faktor-faktor utama dalam pendidikan itu sendiri. Lahirnya Undang-undang Sistem Pendidikan Nasional tahun 2003, Undang-undang No. 14 tahun 2005 tentang Guru dan Dosen, kemudian Peraturan Pemerintah No. 19 Tahun 2005 tentang Standar Nasional Pendidikan dan (Permendiknas) nomor 12 tahun 2007 tentang Standar Pengawas Sekolah/Madrasah, ${ }^{2}$ pada dasarnya merupakan kebijakan pemerintah yang didalamnya memuat usaha pemerintah untuk menata dan memperbaiki mutu pendidikan di Indonesia. Perubahanperubahan tersebut diharapkan dapat memecahkan berbagai permasalahan pendidikan, baik masalah-masalah konvensional maupun masalah-masalah yang muncul bersamaan dengan hadirnya ide-ide baru (masalah inovatif). Di samping itu, melalui perubahan tersebut diharapkan terciptanya iklim yang

\footnotetext{
${ }^{2}$ Direktorat Jenderal Pendidikan Islam Departemen Agama RI, Undang-undang dan Peraturan Pemerintah RI Tentang Pendidikan, Tahun 2006.
}

kondusif bagi peningkatan kualitas pendidikan dan pengembangan sumber daya manusia (PSDM), hal ini tentu demi mempersiapkan bangsa Indonesia memasuki era globalsasi dan era milenial.

Perubahan-perubahan di atas, menuntut berbagai tugas yang harus dikerjakan oleh para tenaga pendidik dan kependidikan sesuai dengan peran dan fungsinya masing-masing, mulai dari level makro sampai pada level mikro, yakni tenaga kependidikan di sekolah. Di sekolah terdapat dua sosok yang paling berperan dan sangat menentukan kualitas pendidikan, yakni kepala sekolah dan guru. Dalam perspektif globalisasi dan era milanial, otonomi daerah, dan desentralisasi pendidikan serta untuk menyukseskan manajemen berbasis sekolah dan kurikulum berbasis kompetensi, kepala sekolah merupakan figur sentral yang harus menjadi teladan bagi para tenaga kependidikan lain di sekolah, dan demi mencapai semua itu tentu harus ada pengawas pendidikan, hal ini sesuai dengan Peraturan Pemerintah Nomor 19 Tahun 2005 tentang standar nasional pendidikan menjelaskan bahwa pengawasan pada pendidikan formal dilakukan oleh pengawas pendidikan (pasal 39 ayat 1). Sedangkan untuk pendidikan non formal dilakukan oleh penilik satuan pendidikan (pasal 40 ayat 1). ${ }^{3}$ Dari latar belakang diatas maka permasalahan yang akan dibahas adalah yang menjadi kewenangan kepemimpinan kepala sekolah sebagai supervisor, kompetensi yang dimiliki, hak-hak melekat yang disandang pada pimpinan sekolah dan pihak terkait dalam tatalaksana supervisi pendidikan Islam

\footnotetext{
${ }^{3}$ Direktorat Jenderal Pendidikan Islam Departemen Agama RI, Undang-undang dan Peraturan Pemerintah RI Tentang Pendidikan, Tahun 2006.
} 


\section{B. Pembahasan}

1. Pendidikan

Islam melihat, bahwa pendidikan merupakan dasar dan sendi-sendi kehidupan dari semua aspek. Baik itu yang berhubungan dengan urusan dunia maupun urusan akhirat. Dalam kontek pendidikan Islam sangat konten dan terkait langsung dengan perintah belajar, sebagaimana Allah telah memfimankan kalam-Nya dalam Surah al-Alaq ayat 1- 5 .

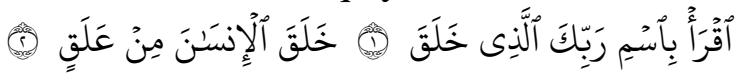

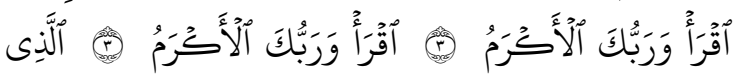

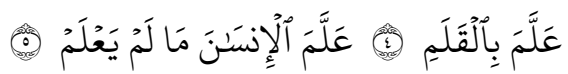

Bacalah dengan (menyebut) nama Tuhanmu yang Menciptakan. Dia telah menciptakan manusia dari segumpal darah. Bacalah, dan Tuhanmulah yang Maha pemurah. Yang mengajar (manusia) dengan perantaran kalam. Dia mengajar kepada manusia apa yang tidak diketahuinya. ${ }^{4}$

Pada ayat tersebut di atas menunjukkan perintah untuk membaca. Membaca adalah merupakan bagian dari unsur pendidikan yang sangat urgen dalam ranah pendidikan. Ayat tersebut juga memuat perintah betapa pendidikan itu saatlah menjadi tolok ulur setiap insan yang akan menjadi manusia yang berkualitas dalam hal urusan dunia, baik ibadah, pekerjaan, status sosial, dan ekonomi. Dan dalam konteks kehidupan manusia sangat terkait dengan pendidikan dalam berbagai bentuknya yang dinamis. Dalam Kamus Besar Bahasa Indonesia kata "pendidikan" berasal dari kata "didik" yang artinya memelihara dan memberi latihan mengenai akhlak dan kecerdasan pikiran. Maka kata "pendidikan" dapat diartikan sebagai proses pengubahan sikap dan tata laku seseorang atau kelompok

\footnotetext{
${ }^{4}$ Kementrian Agama Republik Indonesia, AlQuran dan Terjemahnya
}

orang dalam usaha mendewasakan manusia melalui upaya pengajaran dan latihan. $^{5}$

Menurut Prof. Drs. Piet A. Sahertian, pendidikan adalah usaha sadar yang sengaja dirancang untuk mencapai tujuan yang telah ditetapkan. Pendidikan bertujuan untuk meningkatkan kualitas sumber daya manusia. ${ }^{6}$ Dalam pada itu Prof. Dr. H. Syaiful Sagala, M.Pd. dalam bukunya Supervisi Pembelajaran dikemukakan, bahwa pendidikan merupakan upaya memberikan layanan belajar dengan memperhatikan kualitas di sekolah yang diselaraskan dengan tuntutan UUSPN No. 20 tahun 2003 Pasal 12 ayat 1 dimana dinyatakan bahwa setiap peserta didik pada setiap satuan pendidikan berhak a) mendapatkan pendidikan sesuai dengan agama yang dianutnya, b) mendapatkan layanan pendidikan sesuai dengan minat bakat dan kemampuannya, c) mendapat beasiswa bagi siswa berprestasi, d) bantuan biaya bagi siswa yang orang tuanya tidak mampu, e) dan mendapatkan biaya pindah program ke program lain yang setara. ${ }^{7}$ Pndidikan juga dipandang sebagai bagian integral dalam proses pembangunan bangsa yang dibangun atas empat pilar paradigma pendidikan, yaitu: Pertama, bahwa pendidikan itu untuk semua warga. Kedua, proses pendidikan dijalankan secara demokratis. Ketiga, pendidikan sejatinya memperhatikan dan bertumpu pada kebudayaan lokal. Keempat,

\footnotetext{
${ }^{5}$ Departemen pendidikan dan Kebudayaan, Kamus besar bahasa Indonesia, Balai Pustaka, Jakarta, Cet. III, 1990.

${ }^{6}$ Piet A.Sahertian, Prof. Drs., Konsep Dasar \& Teknik Supervisi Pendidikan, Rineka Cipta, Jakrta,Cet. II, 2008.

${ }^{7}$ Syaiful sagala, H. Prof. Dr. M.Pd., Supervisi Pembelajaran, Alfabeta, Bandung, Cet. I, 2010
} 
pendidikan juga harus menuju tercapaianya keseimbangan antara imtaq dan iptek. ${ }^{8}$

Bertitik-tolak dari apa yang dikemukakan oleh para pakar tentang pendidikan sebagai suatu proses upaya membangun perubahan kehidupan manusia secara sadar berkesinambungan, maka pendidikan bagi terciptanya kehidupan manusia merupakan kebutuhan dan keharusan. Dalam upaya mencapainya apa yang menjadi visi dan misi pendidikan dalam lembaga di manapun diperlukan adanya sistem supervisi yang dilakukan oleh supervisor.

2. Arti Supervisi dan Kewenangan

Allah SWT, berfirman dalam QS: al-Isra/17 ayat: 84

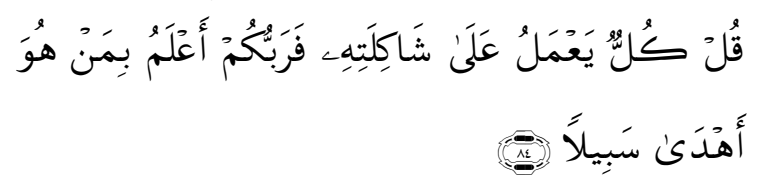

Katakanlah: "Tiap-tiap orang berbuat menurut keadaannya masing-masing". Maka Tuhanmu lebih mengetahui siapa yang lebih benar jalanNya. ${ }^{9}$

Berdasarkan pemahaman ayat di atas dapat kita ambil makna dan kandungan yang dapat kita pahami, bahwa setiap orang harus bekerja sesuai keahliannya dan tugas masing-masing. Termasuk dalam tabi at dan pengaruh alam sekitarnya. Menurut Kamus Besar bahasa Indonesia, kewenangan adalah hak yang melekat dalam kekuasan untuk menentukan, merumuuskan dan atau memutuskan sesuatu hal. Secara historis mula-mula diterapkan konsep supervisi yang tradisional, yaitu pekerjaan inpeksi, mengawasi dalam arti mencari kesalahan dan menemukan kesalahan dengan tujuan untuk diperbaiki. Tindakan supervisi

\footnotetext{
${ }^{8}$ Mukhtar, H. Prof. Dr., M.Pd., Orientasi Baru Supervisi Pendidikan, Gaung Persada Press, Jakarrta, Cet. Pertama, 2009.h. 4-5.

${ }^{9}$ Kementrian Agama Republik Indonesia, $\mathrm{Al}$ Quran dan Terjemahnya
}

tradisional disebut sooper vision yaitu tugas memata-matai untuk menemukan kesalahan. $^{10}$ Konsep supervisi secara demikian, dikemukakan pula sebagai ; inspeksi, pemeriksaan, pengawasan atau penilikan. Maka kata "supervisi" berasal dari dua kata yaitu super dan vision. Kata "Super" artinya di atas dan "Vision" artinya melihat (masih serumpun dengan kata inspeksi, pemeriksaan dan pengawasan, dan penilikan dalam arti kegiatan yang dilakukan oleh atasan orang yang berposisi di atas, yaitu pimpinan-terhadap hal-hal yang ada di bawahnya yaitu yang menjadi bawahannya. Jadi supervisi merupakan langkah melihat bagian mana dari kegiatan di sekolah yang masih negatif untuk diupayakan menjadi positif, dan melihat mana yang sudah positif untuk dapat ditingkatkan menjadi lebih positif lagi, yang penting adalah pembinaan. Hal demikian, merupakan jangkauan pembinaan komponen-komponen dan aspek-aspek oprasional kemanajerialan di sekolah. $^{11}$ Dalam Manajemen Berbasis Sekolah, diungkapkan aspek komponenkomponen sekolah itu yang dijangkau dalam supervisi adalah: 1) Bidang kurikulum dan program pengajaran, 2) bidang Tenaga Pendidik dan kependidikan, 3) bidang Kesiswaan, dan 4) bidang Keuangan dan pembiayaan, 5) Sarana dan Prasarana Pendidikan, 6) dan komponen hubungan sekolah dengan masyarakat. ${ }^{12}$

Bahkan dalam buku Orientasi Baru Supervisi Pendidikan (Prof. Dr. H. Mukhtar, M.Pd. dan Dr. Iskandar, M.Pd, 2009: 10 dikemukakan begitu pentingnya peranan kepala sekolah dalam

${ }^{10}$ Piet A. Sahertian, Prof. Drs., Konsep Dasar \& Teknik Supervisi Pendidikan, Rineka Cipta, Jakrta, Cet. II, 2008.h.16.

${ }^{11}$ Suharsimi Arikunto, Prof. Dr. Dasar-dasar Supervisi, Rineka Cipta, jakarta, Cet. I, 2006.h.1-3.

${ }^{12}$ Dr. E. Mulyasa, M.Pd, Manajemen

Berbasis Sekolah, 2004: h.39-51 
mengembangkan supervisi kinerja tenaga pendidikan dan kependidikan dengan tujuan meningkatnya produktivitas kinerja sekolah. Langkah-langkah sebagai kewenangkan Kepala Sekolah sebagai Supervisor terutama terhada tenaga pendidik (guru), adalah: 1) perencanaanperencanaan ketenagaan yang dibutuhkan, 2) Rekrutmen, 3) Seleksi, 4) Place (penempatan), 5) penampilan kinerja (Performan), 6) Pelatihan dan pengembangan SDM, 7) Kompensasi, 8) Keselamatan kerja, 9) Pengembangan karir, 10) Kelanjutan dari purnabakti. Kesemuanya itu merupakan langkahlangkah dalam lingkup kinerja yang menjadi tanggung jawab dedikatif dan kehandalan kompetensi supervisor. ${ }^{13}$ Istilah kewenangan agaknya akan lebih menukik dalam kepemimpinan sekolah jika disepadankan dengan istilah kompetensi. Konsep mengenai kompetensi untuk pertamakalinya dipopulerkan oleh Boyatzis (1982) yang mendefinisikan kompetensi sebagai kemampuan yang dimiliki seseorang yang nampak pada sikapnya yang sesuai dengan kebutuhan kerja dalam parameter lingkungan organisasi dan memberikan hasil yang diinginkan. Pandangan ini mengindikasikan bahwa kompetensi merupakan karakteristik atau kepribadian (traits) individual yang bersifat permanen yang dapat mempengaruhi kinerja seseorang.

3. Kepala Sekolah Sebagai Supervisor

Kepala sekolah adalah orang yang diberi tanggung jawab untuk mengelola dan memberdayakan berbagai potensi masyarakat serta orang tua untuk mewujudkan visi, misi dan tujuan sekolah. Perubahan pertama terjadi sejak ditetapkan Kepmendikbud RI nomor : 0296/U/1996

${ }^{13}$ Mukhtar, H. Prof.Dr., M.Pd., Orientasi Baru Supervisi Pendidikan, Gaung Persada Press, akarrta,Cet. Pertama, 2009.h.10. tanggal 1 Oktober 1996 sampai dikeluarkannya Kepmendiknas RI Nomor 162/U/2003 tentang Pedoman Penugasan Guru sebagai Kepala Sekolah, seorang Kepala Sekolah tidak lagi sebagai pejabat struktural dengan eselon tertentu. Kepala Sekolah "hanya' seorang guru yang atas dasar kompetensinya diberi tugas tambahan mengelola satuan pendidikan. Jadi seorang kepala sekolah pada dasarnya seorang guru, yaitu seorang guru yang dipandang memenuhi syarat tertentu dalam memangku jabatan professional sebagai pengelola satuan pendidikan. ${ }^{14}$

Secara konsepsional, Dr. E. Mulyasa, M.Pd. dalam bukunya manajemen Berbasis Sekolah (2004: 19) mengemukakan bahwa: Kepemimpinan kepala sekolah dalam kinerja bisa mengacu kepada "model" manajemen berbasis sekolah (MBS). Sehingga pimpinan sekolah dapat memformulasikan pola-pola kemanajerialannya secara menyeluruh melalui kolaborasi dan bersinergi dengan pihak-pihak dalam lingkup struktural dan fungsional dari organisasi pendidikan. ${ }^{15}$

Berdasarkan buku berjudul "Indikator Keberhasilan Kepala Sekolah, diterbitkan oleh Direktorat Pendidikan Menengah Kejuruan Direktorat Jeneral Pendidikan dasar dan Menengah Departemen Pendidikan dan Kebudayaan (1995: 3) dikemukakan bahwa pada dasarnya di dalam konteks manajemen, ada tiga faktor kunci yang berperan dalam menentukan keberhasilan kepemimpinan sekolah yaitu: "MAN" (Kepala Sekolah, Guru dan Karyawan), "MATERIAN" (fasilitas, bahan dan infrastruktur) dan "MONEY" (dana). Secara demikian banyak kegiatan dan tugas yang harus

\footnotetext{
${ }^{14}$ Direktorat Jenderal Pendidikan Islam Departemen Agama RI, Undang-undang dan Peraturan Pemerintah RI Tentang Pendidikan, Tahun 2006.

${ }^{15}$ Dr. E. Mulyasa, M.Pd, Manajemen

Berbasis Sekolah, 2004: h.19
} 
dikelola, dipantau, serta dikendalikan oleh Kepala Sekolah. Tuntutan kinerja yang tinggi menuntut kemampuan tinggi dari pimpinan skolah sehingga mampu menggerakkan seluruh komponen dalam organisasi kerja sesuai peran dan fungsinya secara efektif dan efisien. Maka indikator keberhasilan kepala sekolah, adalah mewujud dalam fungsi dan peranan kepemimpinan kepala sekolah terkait dengan : 1) Sebagai manajer (Manager), 2) Pemimpin (Leader), 3) Administrator (Administrator), 4) Wiraswastawan (Entrepreneur), 5) Penyelia (Supervisor), 6) Pembina Iklim Kerja (Climat Maker) dan 7) Pendidik (Educator). ${ }^{16}$

Dengan demikian secara formulstif dan implementatif bahwa seorang kepala sekolah, fungsi efektifnya adalah seperti apa yang dikemukakan oleh Nicholas $M$. Butter, dalam bukunya Azas-Azas Manajemen Modern (Basu Swastha DH., 1996 :4 ) yaitu: 1) berkesadaran dan berusaha mengetahui apa yang telah terjadi, 2) memperhatikan dan mampu melihat sesuatu terjadi, dan (3) bisa membuat sesuatu terjadi. Dalam konteks manajemen, eksistensi kepemimpinan dalam organisasi apapun selalu terkait dengan keharusan adanya elemen-elemen sumber daya sesuai dengan kondisi riil dan ketersediannya. Dalam konteks kinerja kepemimpinan diiringi dengan adanya kewenangan-kewenangan kepemimpinan yaitu: tanggung jawab (responsibilitas), pertanggungjawaban (akkountabilitas), kewenangan (Autoritas), dan pendelegasian. Secara demikian, maka efektifitas kepemimpinan dalam organisasi kerja terkait dengan; perencanaan, pengorganisasian, pengendalian, dan kontrol atau evaluasi.

\footnotetext{
${ }^{16}$ Direktorat Pendidikan Menengah Kejuruan Direktorat Jeneral Pendidikan dasar dan Menengah Departemen Pendidikan dan Kebudayaan 1995. h. 3
}

\section{Kompentensi Kepala Sekolah,}

Pengawas Sekolah dalam Supervisi Pendidikan Secara garis besarnya ruang lingkup supervisi pendidikan meliputui bidang ketatusahaan, ketenagaan, program kegiatan belajar, penilaian perkembangan anak, program kegiatan tahunan, sarana dan prasarana keuangan, disiplin dan tata tertib, pelaksanaan pembinaan professional, hubungan sekolah dengan masyarakat dan UKS serta mekanisme pelaksanaan dan pelaporannya karena hal ini sesuai dengan undang-undang no 20 tahun 2003 tentang Sistem Pendidikan Nasional Bab I pasa I point 1 dijelaskan bahwa pendidikan adalah usaha sadar dan terencana untuk mewujudkan suasana belajar dan proses pembelajaran agar peserta didik secara aktif mengembangkan potensi dirinya untuk memiliki kekuatan spiritual keagamaan, pengendalian diri, kepribadian, kecerdasan akhlak mulia serta keterampilan yang diperlukan dirinya, masyarakat, bangsa, dan Negara.

Supervisi sesungguhnya dapat dilaksanakan oleh kepala sekolah yang berperan sebagai supervisor, tetapi dalam sistem organisasi pendidikan modern diperlukan supervisor khusus yang lebih independent (pengawas sekolah), dan dapat meningkatkan objektivitas dalam pembinaan dan pelakasanaan tugasnya. Jika supervisi dilaksanakan oleh kepala sekolah, maka ia harus mampu melakukan berbagai pengawasan dan pengendalian untuk meningkatkan kinerja tenaga kependidikan. Pengawasan dan pengendalian ini merupakan kontrol agar kegiatan pendidikan di sekolah terarah pada tujuan yang telah ditetapkan. Pengawasan dan pengendalian juga merupakan tindakan preventif untuk mencegah agar para tenaga kependidikan tidak melakukan penyimpangan dan lebih berhati-hati dalam melaksanakan pekerjaannya. Pengawasan dan pengendalian yang dilakukan kepala 
sekolah terhadap tenaga kependidikannya khususnya guru, disebut supervisi klinis, yang bertujuan untuk meningkatkan kemampuan profesional guru dan meningkatkan kualitas pembelajaran melalui pembelajaran yang efektif.

Kepala sekolah sebagai supervisor harus diwujudkan dalam kemampuan penyusun, dan melaksanakan program supervisi pendidikan, serta memanfaatkan hasilnya. Kemampuan menyusun program supervisi pendidikan harus diwujudkan dalam penyusunan program supervisi kelas, pengembangan program supervisi untuk kegiatan ekstra kurikuler, pengembangan program supervisi perpustakaan, laboratorium, dan ujian. Kemampuan melaksanakan program supervisi pendidikan harus diwujudkan dalam pelaksanaan program supervisi klinis, program supervisi nonklinis, dan program supervisi kegiatan ekstra kurikuler. Sedangkan kemampuan memanfaatkan hasil supervisi pendidikan harus diwujudkan dala pemanfaatan hasil supervisi untuk meningkatkan kinerja tenaga kependidikan, dan pemanfaatan hasil supervisi untuk mengembangkan sekolah.

Dalam pelaksanaanya kepala sekolah sebagai supervisor harus memperhatikan prinsip-prinsip:

1. Hubungan konsultatif, kolegial dan bukan hirarkhis.

2. Dilaksanakan secara demokratis.

3. Berpusat pada tenaga kependidikan (guru)

4. Dilakukan berdasarkan kebutuhan tenaga kependidikan (guru).

5. Merupakan bantuan profesional.

Kepala sekolah sebagai supervisor dapat dilakukan secara efektif antara lain melalui diskusi kelompok, kunjungan kelas, pembicaraan individual, dan simulasi pembelajaran. Apa saja kompetensi yang harus dimiliki kepala sekolah dan pegawas sekolah dalam kaitannya dengan supervisi pendidikan?

5. Kompetensi Kepala Sekolah

Ada beberapa kompetensi kepala sekolah dalam supervisi pendidikan, setidaknya ada kesepakatan bahwa kepala sekolah perlu memiliki sejumlah kompetensi berikut terkait supervisi pendidikan (diadaptasi dari CCSSO, 2002), yaitu:

Kompetensi 1:

Memfasilitasi penyusunan, penyebarluasan, dan pelaksanaan visi dan misi pembelajaran yang dikomunikasikan dengan baik dan didukung oleh komunitas sekolah. Kepala sekolah harus dapat memastikan bahwa sekolahnya memiliki visi dan misi yang jelas dan disepakati bersama serta didukung oleh komunitas sekolahnya. Jika visi dan misi itu belum ada, ia harus berinisiatif untuk menyusunnya dengan melibatkan semua pihak yang berkepentingan atas sekolahnya.

Kompetensi 2:

Membantu, membina, dan mempertahankan lingkungan sekolah dan program pengajaran yang kondusif bagi proses belajar peserta didik dan pertumbuhan profesional para guru dan staf. Kepala sekolah harus dapat memastikan adanya lingkungan sekolah yang kondusif. Sekadar mengingatkan, lingkungan belajar yang kondusif memungkinkan orang-orang di dalamnya untuk mendayagunakan dan mengembangkan potensinya seoptimal mungkin. Kepala sekolah misalnya harus berupaya keras agar masalah-masalah sosial, seperti penyalahgunaan narkoba, tidak mengimbas ke dalam lingkungan sekolahnya. Dalam lingkungan seperti itu, para guru dan peserta didik termotivasi untuk saling belajar, saling memotivasi, dan saling memberdayakan. Suasana seperti memberi ruang untuk saling belajar melalui keteladanan, belajar bertanggung 
jawab, serta belajar mengembangkan kompetensi sepenuhnya.

Kompetensi 3:

Menjamin bahwa manajemen organisasi dan pengoperasian sumber daya sekolah digunakan untuk menciptakan lingkungan belajar yang aman, sehat, efisien, dan efektif. Kepala sekolah harus dapat memastikan bahwa apapun prinsipprinsip dan teknik manajemen organisasi dan pengoperasian sumber daya sekolah yang diterapkan semata-mata digunakan bagi kepentingan peserta didik. Ia harus dapat menjamin bahwa lingkungan fisik sekolahnya aman dan sehat bagi peserta didik, guru, dan staf pendukung lainnya Kompetensi 4:

Bekerja sama dengan orang tua murid dan anggota masyarakat, menanggapi kepentingan dan kebutuhan komunitas yang beragam, dan memobilisasi sumber daya masyarakat. Kepala sekolah harus menyadari bahwa tujuan sekolah tidak mungkin dicapai tanpa melibatkan semua pihak yang berkepentingan, utamanya para orang tua murid. Manajemen sekolah adalah upaya bersama agar hal-hal yang tadinya terasa besar dan berat menjadi lebih terkendali. Berat sama dipikul, ringan sama dijinjing. Oleh sebab itu, kepala sekolah harus tidak boleh putus harapan untuk menghimbau dan merangkul semua pihak yang berkepentingan demi kemajuan sekolahnya.

\section{Kompetensi 5:}

Memberi contoh (teladan) tindakan berintegritas. Kepala sekolah pastilah berada dalam posisi yang serba kikuk jika tidak menujukkan kualitas perilaku yang dapat diteladani. Dapat dipercaya, konsisten, komit, bertanggung jawab, dan secara emosional terkendali adalah kualitas yang seharusnya dimiliki para pimpinan. Karakter moral seperti itulah sebenarnya yang memiliki dampak jangka panjang.
Kepala sekolah yang hanya mengandalkan kewenangan jabatannya untuk mempengaruhi lingkungan, hanya akan menimba hasil jangka pendek

Kompetensi 6:

Memahami, menanggapi, dan mempengaruhi lingkungan politik, sosial, ekonomi, dan budaya yang lebih besar. Kepala sekolah perlu menyadari bahwa kehidupan di sekolahnya adalah bagian dari lingkungan kehidupan yang lebih luas. Kehidupan lain di luar sekolahnya ikut berpengaruh dalam upayanya mengelola sekolah dengan baik. Berpikir sistem membantunya untuk memahami posisi sekolahnya dalam gambaran yang lebih besar. Sekolahnya sendiri adalah bagian dari subsistem sosial yang terkait dengan sistem politik, ekonomi, dan lain-lainnya.

Karena kepala sekolah tersebut seorang guru, tentu dalam perspektif kebijakan pendidikan nasional, pemerintah telah merumuskan empat jenis kompetensi guru sebagaimana tercantum dalam Penjelasan Peraturan Pemerintah No 14 Tahun 2005 tentang Standar Nasional Pendidikan, yaitu :

1. Kompetensi pedagogik yaitu merupakan kemampuan dalam pengelolaan peserta didik yang meliputi: (a) pemahaman wawasan atau landasan kependidikan; (b) pemahaman terhadap peserta didik; (c)pengembangan kurikulum/ silabus; (d) perancangan pembelajaran; (e) pelaksanaan pembelajaran yang mendidik dan dialogis; (f) evaluasi hasil belajar; dan (g) pengembangan peserta didik untuk mengaktualisasikan berbagai potensi yang dimilikinya.

2. Kompetensi kepribadian yaitu merupakan kemampuan kepribadian yang: (a) mantap; (b) stabil; (c) dewasa; (d) arif dan bijaksana; (e) berwibawa; (f) berakhlak mulia; (g) menjadi teladan bagi peserta didik dan masyarakat; (h) mengevaluasi kinerja sendiri; dan (i) 
mengembangkan diri secara berkelanjutan.

3. Kompetensi sosial yaitu merupakan kemampuan pendidik sebagai bagian dari masyarakat untuk: (a) berkomunikasi lisan dan tulisan; (b) menggunakan teknologi komunikasi dan informasi secara fungsional; (c) bergaul secara efektif dengan peserta didik, sesama pendidik, tenaga kependidikan, orangtua/wali peserta didik; dan (d) bergaul secara santun dengan masyarakat sekitar.

4. Kompetensi profesional merupakan kemampuan penguasaan materi pembelajaran secara luas dan mendalam yang meliputi: (a) konsep, struktur, dan metoda keilmuan/teknologi/seni yang menaungi/koheren dengan materi ajar; (b) materi ajar yang ada dalam kurikulum sekolah; (c) hubungan konsep antar mata pelajaran terkait; (d) penerapan konsep-konsep keilmuan dalam kehidupan sehari-hari; dan (e) kompetisi secara profesional dalam konteks global dengan tetap melestarikan nilai dan budaya nasional.

6. Pembagian Jenis Supervisi

a. Supervisi Manajerial

1. Menguasai metode, teknik dan prinsip-prinsip supervisi dalam rangka meningkatkan mutu pendidikan.

2. Menyusun program kepengawasan berdasarkan visi-misi-tujuan dan program sekolah-sekolah binaannya.

3. Menyusun metode kerja dan berbagai instrumen yang diperlukan untuk melaksanakan tugas pokok dan fungsi pengawasan.

4. Membina kepala sekolah dalam mengelola satuan pendidikan berdasarkan manajemen peningkatan mutu berbasis sekolah (MPMBS).

5. Membina kepala sekolah dalam melaksanakan administrasi satuan pendidikan meliputi administrasi kesiswaan, kurikulum dan pembelajaran, pendidik dan tenaga kependidikan, sarana dan prasarana, pembiayaan, keuangan,lingkungan sekolah dan peran serta masyarakat.

6. Membantu kepala sekolah dalam menyusun indikator keberhasilan mutu pendidikan di sekolah.

7. Membina staf sekolah dalam melaksanakan tugas pokok dan tanggung jawabnya.

8. Memotivasi pengembangan karir kepala sekolah, guru dan tenaga kependidikan lainnya sesuai dengan peraturan dan ketentuan yang berlaku.

9. Menyusun laporan hasil-hasil pengawasan pada sekolah-sekolah binaannnya dan menindak lanjutinya untuk perbaikan mutu pendidikan dan program pengawasan berikutnya.

10. Mendorong guru dan kepala sekolah untuk menemukan kelebihan dan kekurangan dalam melaksanakan tugas pokoknya.

11. Menjelaskan berbagai inovasi dan kebijakan pendidikan kepada guru dan kepala sekolah.

12. Memantau pelaksanaan inovasi dan kebijakan pendidikan pada sekolahsekolah binaannya.

b. Supervisi Akademik

1. Memahami konsep, prinsip, teori dasar, karakteristik, dan kecenderungan perkembangan bidang ilmu yang menjadi isi tiap bidang pengembangan/mata pelajaran.

2. Memahami konsep, prinsip, teori/teknologi, karakteristik, dan kecenderungan perkembangan proses pembelajaran tiap bidang pengembangan/mata pelajaran.

3. Membimbing guru dalam menentukan tujuan pendidikan yang 
sesuai, berdasarkan standar kompetensi dan kompetensi dasar tiap bidang pengembangan/mata pelajaran,

4. Membimbing guru dalam menyusun silabus tiap bidang pengembangan/ mata pelajaran berlandaskan standar isi, standar kompetensi dan kompetensi dasar, dan prinsipprinsip pengembangan KTSP.

5. Menggunakan berbagai pendekatan/metode/ teknik dalam memecahkan masalah pendidikan dan pembelajaran tiap bidang pengembangan/mata pelajaran.

6. Membimbing guru dalam memilih dan menggunakan startegi/metode/teknik pembelajaran yang dapat mengembangkan berbagai potensi peserta didik melalui bidang pengembangan/mata pelajaran.

7. Membimbing guru dalam menyusun rencana pembelajaran (RPP) untuk tiap bidang pengembangan/mata pelajaran

8. Membimbing guru dalam memilih dan menggunakan media pendidikan yang sesuai untuk menyajikan isi tiap bidang pengembangan/mata pelajaran.

9. Memotivasi guru untuk memanfaatkan teknologi informasi untuk pembelajaran tiap bidang pengembangan/mata pelajaran.

10. Membimbing guru dalam melaksanakan

strategi/metode/teknik pembelajaran yang telah direncanakan untuk tiap bidang pengembangan/mata pelajaran.

11. Membimbing guru dalam melaksanakan kegiatan pembelajaran (di kelas, laboratorium, dan/atau di lapangan) untuk mengembangkan potensi peserta didik pada tiap bidang pengembangan/mata pelajaran.

12. Membimbing guru dalam merefleksi hasil-hasil yang dicapai, kekuatan, kelemahan, dan hambatan yang dialami dalam pembelajaran yang telah dilaksanakan.

13. Membantu guru dalam mengelola, merawat, mengembangkan, dan memanfaatkan fasilitas pembelajaran yang berkaitan dengan mata pelajaran.

7. Evaluasi Pendidikan

a. Membimbing guru dalam menentukan aspek-aspek yang penting dinilai untuk tiap bidang pengembangan/mata pelajaran yang termasuk dalam rumpunnya.

b. Membimbing guru dalam menentukan kriteria dan indikator keberhasilan pembelajaran tiap bidang pengembangan/mata pelajaran yang termasuk dalam rumpunnya.

c. Menyusun kriteria dan indikator keberhasilan pendidikan pada satuan pendidikan yang menjadi binaannya

d. Menilai kemampuan guru dalam melaksanakan pembelajaran pada tiap bidang pengembangan/mata pelajaran yang termasuk dalam rumpunnya.

e. Menilai kemampuan kepala sekolah dalam mengelola satuan pendidikan.

f. Menilai kinerja staf sekolah dalam melaksanakan tugas pokoknya.

g. Menilai kinerja sekolah dan menindaklanjuti hasilnya untuk keperluan akreditasi sekolah.

h. Mengolah dan menganalisis data hasil penilaian kinerja sekolah, kinerja kepala sekolah, kinerja guru, dan kinerja staf sekolah.

i. Memantau pelaksanaan kurikulum, pembelajaran, bimbingan dan hasil belajar siswa serta menganalisisnya untuk perbaikan mutu pendidikan pada sekolah binaannya 
j. Membina guru dalam memanfaatkan hasil penilaian untuk kepentingan pendidikan dan pembelajaran tiap bidang pengembangan/mata yang termasuk dalam rumpunnya

k. Memberikan saran kepada kepala sekolah, guru, dan seluruh staf sekolah dalam meningkatkan kinerjanya berdasarkan hasil penilaian.

8. Penelitian dan Pengembangan

a. Menguasai berbagai pendekatan, jenis, dan metode penelitian dalam pendidikan.

b. Menentukan masalah kepengawasan yang penting untuk diteliti baik untuk keperluan tugas pengawasan, pemecahan masalah pendidikan, dan pengembangan profesi.

c. Menyusun proposal penelitian pendidikan baik proposal penelitian kualitatif maupun proposal penelitian kuantitatif.

d. Melaksanakan penelitian pendidikan baik untuk keperluan pemecahan masalah pendidikan, perumusan kebijakan pendidikan maupun untuk pengembangan profesi.

e. Mengolah dan menganalisis data penelitian pendidikan baik data kualitatif maupun data kuantitatif.

f. Memberikan bimbingan kepada guru tentang penelitian tindakan kelas, baik perencanaan maupun pelaksanaannya.

g. Menyusun karya tulis ilmiah (KTI) dalam bidang pendidikan/kepengawasan.

h. Mendiseminasikan hasil-hasil penelitian pada forum kegiatan ilmiah baik lisan maupun tulisan.

i. Membina guru dalam menyusun karya tulis ilmiah dalam bidang pendidikan dan pembelajaran.

j. Membuat artikel ilmiah untuk dimuat pada jurnal.

k. Menulis buku/modul untuk bahan pengawasan.
1. Menyusun pedoman/panduan yang diperlukan untuk melaksanakan tugas pengawasan.

\section{Kesimpulan}

1. Kepala sekolah sebagai supervisor dalam suatu lembaga pendidikan mempunyai hak-hak yang melekat sebagai konsekuensi dari tuntutan tanggung-jawabnya yang tidak ringan untuk membangun kualitas pendidikan di sekolah.

2. Besarnya tanggung-jawab pimpinan sekolah sebagai supervisor menuntut kompetensi yang tinggi serta kemampuan

mengoprasionalisasikannya ke dalam langkah supervisi yang terkonsep, cermat dan terprogram sesuai dengan kewenangannya.

3. Tingginya kemampuan dan kompetensi kepala sekolah sebagai supervisor dapat dilihat dalam efektifitas kinerja melalui output dan outcome dari lembagapendidikan yang dipimpinnya.

\section{DAFTAR PUSTAKA}

Departemen Agama Republik Indonesia, Al-Quran dan Terjemahnya

Direktorat Jenderal Pendidikan Islam Departemen Agama RI, Undangundang dan Peraturan Pemerintah RI Tentang Pendidikan, Tahun 2006.

Departemen pendidikan dan Kebudayaan, Kamus besar bahasa Indonesia, Balai Pustaka, Jakarta, Cet. III, 1990

Direktorat Pendidikan Dasan dan Menengah Departemen Pendidikan dan Kebudayaan, Indikator Keberhasilan Kepala Sekolah, 1995

Made Pidarta, Supervisi Pendidikan Kontekstual, Rineka Cipta, jakata, Cet. I, 2009 
Mukhtar, Orientasi Baru Supervisi Pendidikan, Gaung Persada Press, Jakarrta, Cet. Pertama, 2009

Mujamil Qomar, Manajemen Pendidikan Islam, Erlangga, Malangg, Cet. I, 2007

Mulyasa E., Manajemen Berbasis Sekolah, Rosda , Bandung, Cet. VII, 2004
Piet A. Sahertian, Konsep Dasar \& Teknik Supervisi Pendidikan, Rineka Cipta, Jakrta, Cet. II, 2008

Suharsimi Arikunto, Dasar-dasar Supervisi, Rineka Cipta, jakarta, Cet. I, 2006

Syaiful sagala, Supervisi Pembelajaran, Alfabeta, Bandung, Cet. I, 201 
Supervisor Pendidikan Islam Dalam Perspektf Al-Qur`An

Rausyan Fikr. Vol. 16 No. 1 Maret 2020. ISSN. 1979-0074 e-ISSN. 9772580594187 | 62 